\title{
Subjectives and biotechnologies in umbilical cord-trunk bodies: Addresses to psychology.
}

\author{
Renata Vilela Rodrigues ${ }^{1}$, Dolores Galindo ${ }^{1}$ and Flavia Cristina Silveira Lemos ${ }^{2 *}$ \\ ${ }^{1}$ Federal University of Mato Grosso, Brazil \\ ${ }^{2}$ Federal University of Pará, Brazil
}

\begin{abstract}
This article aims to problematize the marketing network that markets the stem cells present in the umbilical cord through the analysis of statements made by relatives about their relationship with the umbilical cord, collected on homepages of Brazilian private banks. Based on the Foucaultian archegenealogical studies, we argue that one of the facets of contemporary biopolitics is centered on the regulation and normalization of bodies and health, as well as the accumulation of biological capital through the autologous storage of umbilical cells. It is specifically a cut of a master's research carried out by the research laboratory in "Science, Technology and Creation", within the scope of the Graduate Program in Contemporary Culture Studies, Federal University of Mato Grosso. In this work, we call attention to the forms of subjectivity that emerge in the commercialization of umbilical stem cells, characterized mainly by self-management and indebtedness.
\end{abstract}

Keywords: Biopolitics, Subjectivies, Biotechnologies, Culture, Psychology.

Accepted on January 18th 2018

\section{Introduction}

This article is an analytical essay, extracted as part of a historical documentary research in Social Psychology, using primary sources, selected in Internet pages, linked to the health market, organized under the promise of disease prevention. Among the main documentary sources studied are those of CordCell and those of Criocord, raised and analyzed through the genealogical method of Michel Foucault, in which there is the description and interrogation of practices of knowledge and power, from a perspective of the political history of truth. The custody of stem cells from the umbilical cord of children has become a practice of parents, which have become subjectivated by the preventive aspect of health as a value, in a bioeconomy, a biovalue. Life as value to be managed was marketed and gained status of product and consumption, health market to be governed by guarding banks in the form of biotechnology companies.

With the appearance of biotechnologies in doctors' offices, laboratories, trades and, consequently, in the daily life of people, the way we subjectivate ourselves is increasingly crossed by these biotechniques. We are taking responsibility for our future medical and our family's; and, as we begin to experience our lives in biomedical terms, our subjectivities are being shaped by genetic counseling, new languages to describe health, and new criteria for calculating hazards and risks [1,2]. Faced with the diversity of biotechnological and genetic techniques and the possibility of tracking the pathologies that may affect us, complex and diffuse feelings afflict people who invest their financial capital, their own body and their hopes in the various biotechniques.

Biotechnologies and demands on health, exemplified in the present research through the marketing of autologous umbilical cells, emerge worried and fearful individuals who experience their health in terms of the probabilities of the development of some disease in the future and that, gradually, demand resources every time more advanced in Regenerative Medicine.

It is noteworthy that we understand that the development of contemporary subjective modulations is crossed by various sabers, such as economics, biology, psychiatry, medicine, law, psychology, as well as between power relations engendered as specific truth games about the techniques we use, to understand ourselves [3].

We can not fail to mention the role that biomedicine has played in the production of contemporary subjectivities. This area of knowledge and action is increasingly treating subjects as presymptomatically ill patients who, because they carry a genetic code and are vulnerable to the various conditions of existence, will one day become ill and die. Although applications for autologous transplants are not proven, today private stem cell banks offer a "unique opportunity" for families to bet on the future evolution of biomedicine if their child or someone in the family develops some kind of disease that new generation of cell therapies can treat [4].

We agree with Rose [2,5], when she states that biomedicine has not only changed our relationship to health and disease, but it has helped make us the kinds of people we have become. For the author, we are increasingly relating to ourselves as somatic individuals, that is, as beings whose subjectivity is produced, in part, as a consequence of our biology. Therefore, we are increasingly experimenting, articulating, judging and acting upon ourselves in the language of biomedicine. This can be seen, for example, in the section that opens the present article, taken from a website created by a Brazilian bank to address 
doubts of future parents regarding the advances in umbilical cord stem cell therapy.

\section{Of the Methodological Resource}

In this research, we use 19 homepages of private banks, from which we can collect various relevant information, since these help to visualize and problematize the entrance of the umbilical cells in the biopolitical strategies of the neoliberal market, besides giving visibility to the forms of subjectivity that emerge from it. The choice of private banks is due to the large number of information and the intense activity found in its pages, which was not visualized in the public banks that, in some cases, did not even own websites.

The statements of private banks were collected between June 2013 and 2018, at which time the data collection of the master's research was developed. Taking into consideration that the internet is a space where information is constantly updated and lost, we opted to update the information collected, in 2018.

The methodological corpus of this research works as a critical incident, which are configured as small key events that allow to investigate what is desired, and the incidents are not necessarily the study of major events or documents considered important from a historical point of view. In this direction, critical incidents do not form from a gradual analysis of an event, but may be small moments considered important within this larger event $[6,7]$.

Thus, certain documents, time intervals, or any event that is important to enable and trace the networks that compose the social network [8] are constituted as critical incidents. Critical incidents may also involve the mobilization of actors around certain scientific facts or biopolitical strategies in the health area, such as the one that occurs in this research.

We emphasize that our research will only use public domain data, that is, unrestricted access present on the Internet. For the use of testimonies taken from the homepages of private stem cell banks, we followed Law No. 9.610 of February 19, 1998, which amends, updates and consolidates copyright legislation and which, in chapters IV and $\mathrm{V}$, on the reproduction of photographs and audiovisual works, provided the original source is mentioned. Regarding research ethics, we follow CNS resolutions No. 466/12 and its normal operational number $001 / 2013$ and CFP $n^{\circ} 016 / 2000$, which provide for ethics in research involving, directly or indirectly, human beings.

\section{The Management of Insecurity in the Production of Subjective}

In his studies, Foucault engages in the argument that all knowledge is also the effect of a practice of power; thus, one can not allude to a pure and disinterested knowledge [9]. In this sense, what we visualize in the biopolitical strategies of control and manipulation of the umbilical cord stem cells, are subjections that emerge in a complex network of biotechnological production, which they learn to be affected by the pulsation of the blood when they are born and, in case of the development of some pathology, by the return of that same part to the body. We have become part of a broad collective bargaining that involves a heterogeneous network of capitalist production, types of human beings and nonhumans, entities and hybrids, health and disease [10].

The subject and his/her self-end up being an indispensable element in the politics that configures the liberal societies of the eighteenth and nineteenth centuries and the neoliberal of our day [11]. The network of governance of which biotechnologies are a part indicates the constitution of a new rationality of government, whose power produces a set of "dynamic relationships between those who 'advise' and those who are 'advised' and summoned to take responsibility for their living and health conditions". We are involved in a power that deals with both body and life, or that deals with life in general, with the pole of the body and the pole of the population [12].

In this governmental rationality, we operate as a category "in constant danger" and we are obligatorily entering the futurological space of probabilities. People are guided by biosafety criteria and bioethical paradigms: we are all considered a category of risk, even if we do not present evident signs of illness. In other words, the rationality of medical devices generates a search for predictability in relation to the clinical picture that may occur in the future and, paradoxically, does not necessarily produce certainty, confidence and tranquility [13]. We deal with a virtual illness, as Pimentel and Bruno [14] point out: "... a regime of cares and concerns regarding the virtualities of the body - the diseases that can be had, aging to retard, the life expectancy to increase".

In this direction, we are at the same time healthy and ill, pointing to a regime of power that operates in an open environment and a precautionary regime characterized by selfmonitoring. Foucault [15], in the Birth of Biopolitics, already stressed that, as the main characteristic of biopolitics is its forward-looking vision, regulatory strategies are created to provide interventions in the direction of reformatting the future of human health, acting in the vital present. Allied to biopolitical strategies, the ideals of self-consciousness to be healthy and perfect health have become new paradigms in our neoliberal societies [16].

The path that leads to good health depends essentially on responsible individual actions [13], which generate movements of interests between companies, political and economic relations of a country. The umbilical cord stem cell health consumer market has harnessed these interests and investments in improving the bodies and preventing risks by providing technologies that allow the tracking of the probable diseases and investments available to treat them, when developing.

In the management of insecurity, prevention has become an increasingly present element in the daily lives of people, mainly due to the medicalization of nonexistent. Prevention is understood as "[...] interventions aimed at avoiding the emergence of specific diseases, reducing their incidence and prevalence in populations. The basis of preventive discourse is epidemiological knowledge", which attempts to control the transmission of infectious diseases and reduce the risk of degenerative diseases [17]. 
Citation: Rodrigues RV, Galindo D, Lemos FCS. Subjectives and biotechnologies in umbilical cord-trunk bodies: Addresses to psychology. $J$ Psychol Cognition 2019;4(1):6-14.

Castiel and Alvarez-Dardet [13] propose the term metaprevention to designate the hyperprevention generated by increasingly persecutory dimensions of current strategies in promotion and prevention, in the current health practices. For the authors, there is some persecutory in the idea of knowing the future in order to prevent the various pathologies that can and will affect us. It is worth mentioning that preventive practices are not so recent. Foucault [18] shows that, since the end of the 19th century, preventive measures have been taken in order to act on moral, social and political deviations. Any behavior considered deviant in relation to the current norm could be subject to therapeutic practices.

According to Guareschi, et al. [19], prevention and precaution, coupled with genetic activities and biotechnologies, have made possible a double play of guardianship and guilt in health practices, in which the success of good health should be credited to efforts of the subject itself; however, if he does not succeed, he should feel guilty for not using all the techniques available in the health market. The concept of health, in this perspective, allows the government to intervene not only in biological processes, but also in the subjective, social, affective and economic processes.

The processes of subjectivation are constituting technical lines and biossociabilities administered and capitalized economically and politically, in the name of the security society: constant monitoring, paranoia and prevention practices based on vigilance [20]. In a way, we gain autonomy and freedom, but the autonomy to watch ourselves and the freedom to become experts, experts of ourselves, our health, our body [16].

Rabinow [21] points out how biossociabilities are being forged, where struggles are fought by the right to manipulate the genetic code, and groups organize themselves into demands, in function of gene naming or the risk of developing a particular disease, for have a supposed genetic predisposition. In the biosocialities, the actions of the people are directed with the objective of obtaining better physical form, more longevity, prolongation of the youth etc. Biomedical strategies, based on biological constants, cholesterol rates, muscle tone, body performance, aerobic capacity, become popular and provide the assessment principles that define the individual's excellence. The rules of biosocialities emphasize and form subjects who self-control, self-refer and self-govern [16]. An interesting example of biosocialities can be seen in Rose's [5] work on AIDS activists in the English-speaking world:

AIDS activists organized themselves into groups, and constituted as "communities" those who were actual or potential sufferers of the disease - communities in the name of which they would speak, and for which they were responsible. These groups had a number of roles: to disseminate information about the disease, to campaign for rights and to combat stigma; support those affected by the disease; develop a series of techniques for the day-to-day management of the disease; seek alternative forms of treatment; and solicit their own opinion on the development and use of medical expertise [5].

The complexity surrounding the biosafety formation of the HIV and AIDS activist community is exemplary, because gradually, as Rose [5] points out, an alliance has been formed between activists and the conventional biomedical community. The activist community has provided key elements and information relevant to the domain of the virus to the scientific community as it has led biomedicians to gain the trust of active homosexuals and thereby hold them accountable as biological citizens who must manage their health. On the other hand, the activists had the opportunity to comment on the organization and use of social resources and obtained the necessary means to carry out their activities.

\section{Biossocialities in Regenerative Medicine}

Biomedicine biossocialities and biotechnologies are forged by groups of patients who use and demand services in Regenerative Medicine and Genetic Engineering. The relationship between these patients and the public and private companies in Regenerative Medicine is characterized by the translation of interests, in which the homepages function as mediators of the transportation of the information and services made available by the companies to the parents, indicating which they move more activities in regenerative medicine, as well as which ones have the highest national and international certifications and, with this, they pass greater confidence. Companies, in turn, use virtual spaces as a tool for advertising their business.

The biossocialities formed from activities in biomedicines, more specifically through developments in human genetics, are characterized by creating new individual and family biotic responsibilities:

When a disease or pathology is considered genetic, it is no longer an individual subject. It has become familiar, as much a question of family histories as of future potential families. In this way, genetic thinking produces "genetic responsibility": it reshapes the prudence and obligation in relation to marriage, children and the pursuit of a career and the organization of financial affairs [5].

We should emphasize that biossocialities are performed differently in each region, so that the biossocialities forged in Brazil will not be identical to those formed in Europe, which in turn differ from those in the United States. These new selftechnologies model subjectivities linked to the emergence of complex ethics around the management of biological and social existence [5].

In the Brazilian banks of umbilical cord stem cells, we visualize the production of self-technologies that give rise to frightened and gambling subjectiveities. In its frightening character, parents and children are mobilized by fear of unwanted illness. In their gambling character, people are guided in terms of hope and bets on the future of Regenerative Medicine. In the same direction, Waldby [10] argues that companies such as stem cell banks attract "clients" not only 
because they exaggerate present and future risks that they may need stem cell transplantation, but also because they offer a way of popular participation in the advances of biotechnologies. To exemplify the emergence of frightened and gambling subjectivity, note the deposition left by a mother in the private bank Criocord:

"What led me to decide for the collection of my daughter's stem cells was to believe in the possibility of cure for various diseases that may affect my daughter in the future. I know that the stem cells stored in the Criocord can be used in case of need for bone marrow transplantation. I know, too, that there is a great deal of ongoing research going on to consolidate the use of CT to regenerate damaged tissues and cure diseases now considered incurable" (Source: http:// www.criocord.com.br/).

The commercialization of umbilical cells in private banks is fueled by fears of the still undetected disease and the uncertainties of stem cell research. In the following statement, written by a mother who collected and stored the umbilical cord blood from her son at the Brazilian bank Hemocord, we can see that the action of storing the umbilical cord is taken as an act of precaution, aiming at the prevention of diseases. Such action is fueled by fear of future sickness and by the hope that, in the not too distant future, new biotechnologies and techniques in Regenerative Medicine will be able to extend the therapeutic power of umbilical cells:

"In 2011, I discovered that I was pregnant with my second child. As it was with the first, I decided to collect umbilical cord blood because as a doctor I work with children with cancer and I consider this material extremely valuable to be thrown away along with the cord and placenta at the time of delivery".

"I chose Hemocord for several reasons: first, it is an extremely well-respected and ethical laboratory. Secondly because it offers a very comfortable structure for the pregnant patient. At the moment we are arriving at the hospital, the collector is already in the care of the obstetrical center, without the need for more concern on the part of the pregnant woman who at that time already have other issues to worry about. Third: The material is stored in safe containers and without risk of loss of material due to improper packaging. During pregnancy, the Hemocord team monitors obstetric consultations and is always alert to any eventualities, such as premature labor and, finally, the values collected for the collection of cord blood and its packaging are extremely feasible, if compared with other laboratories".

"The collection of umbilical cord blood is an issue that is currently very contradictory and several professionals have not [sic] indicated this procedure for many reasons. As I am an onco-pediatrician, I believe that the packaging of this material can guarantee my children an additional possibility in the cure of genetic, oncological and other diseases to be studied. I think the amount spent for this collection is very small compared to the many benefits it can bring to my children, cases [sic] they will one day need to use their own cord blood. I encourage my patients' parents to make this investment because I consider it as a small savings that can guarantee future unforeseen circumstances".

"And for how long will I leave this material conditioned? I intend to have this material indefinitely. Medicine has evolved a lot in recent decades and it is still going much further. We do not know where we are going to get, nor even what diseases we will find in the front. Many of them today incurable, tomorrow can become curable through stem cells, so I do not even think about discarding this material that is very well stored in Hemocord". (source: http://www.hemocord.com.br/).

The testimonies found on the homepages of stem cell banks are advertising strategies that aim to convince parents to collect and store the umbilical cord. It is worth mentioning that even the statements made by mothers are the banks that choose which ones go to the company's homepage. In the above testimonial, for example, a woman as a mother who used the services of the hemocord company reports on her experience during pregnancy and childbirth as an expert in oncologypediatrics shows prospective fathers the importance of umbilical cord stem cells and as consumer of the products in Regenerative Medicine their satisfaction and happiness with the company and the prices offered.

Storing umbilical cord blood becomes an activity that paradoxically combines the production of hope for perfect health and anxiety, fear and even paranoia about which biological future someone or those we love may have. The subjectivities in stem cell banks are built and established through a network of governance involving specialists, biomedicine experts, laboratories, parents, umbilical cord collection and storage activities and marketing strategies.

The conception of medical techniques that construct cautious and frightened people is proposed by Castiel and ÀlvarezDardet [13] to discuss the persecutory health of the contemporary. According to the authors, persecutory health is characterized by risk virtualization: "... people are at risk, even if they do not show obvious signs of illness, but by evidence provided by the many medical devices available for prospecting and surveillance" [13]. The discourse that we can develop some pathology and we must be attentive to this, generated by the available medical surveillance devices, thus produce subjectivities that are constructed from a rationality, but which, because they are not characterized by certainty and consistency, do not provide security and tranquility. On the contrary, they provide persecutory and fearful thoughts about future illness $[13,22]$.

\section{Entrepreneurship of Self in the Private Banks of Stem Cells: From Homo Oeconomicus to Indebted Man}

The private banks of umbilical cord stem cells draw our attention because they have a form of technology and industry that modulates modes of subjectivity, characterized by both fear and caution, self-entrepreneurship, risk management, and collaboration in the future. biotechnology. In these companies, conditions are created for people to self-govern because of the 
Citation: Rodrigues RV, Galindo D, Lemos FCS. Subjectives and biotechnologies in umbilical cord-trunk bodies: Addresses to psychology. $J$ Psychol Cognition 2019;4(1):6-14.

reference of a safer and healthier life to their family in the future [23]. In this topic, we will present, through the analysis of the testimonies found on the homepages of the private stem cell banks, how parents become entrepreneurs of themselves and how they learn to be indebted in the current market economy.

Self-management is described by Foucault [15], when it refers to a certain type of investment made at the level of the subject itself, which is seen as a company, whose living conditions are the income of a capital. In neoliberalism, the entrepreneur himself is represented in the figure of the homo oeconomicus who invests in himself to obtain his own improvement.

For Foucault [15], the homo oecomicus consists of a new figure that emerges in the commercial relations between State and neoliberalism. The economic man is the individual seen as a company, an investor and at the same time an investment. By its heterogeneous character, the economic man is one whose personal interest is so governamentalizable that, spontaneously, it will converge with the interest of the others. According to Lazzarato [24], this economic man is one who "integrates himself with all economic subjects, not by a transfer of rights, but by a spontaneous multiplication of interests".

The economic man, as an entrepreneur, has two main characteristics: 1) consumer of technological innovations and 2) subject of interest. As a consumer, he, while consuming business services and techniques, is a producer of his own satisfaction. As a subject of interest, he is not one that adheres to the market economy, but participates in it when he has the will, because it can bring him some benefit [15]. Interest appears as a form of will that is absolutely subjective. In this conception, the market is not defined by man's instincts in making exchange, but by his interests. By market one understands a relation of competition and inequality, in which the subjects are not merchants, but entrepreneurs [24]. Work ceases to be the only currency of the human being, which starts to manage and market itself with companies and biomedical centers, aiming to improve their health and, consequently, to increase longevity.

Taking market values in your life becomes the economic man's obligation in order to accumulate sufficient amounts of "human capital" and thus become an entrepreneur. It is not a natural being, with predictable forms of conduct and behavior, but a form of subjectivity that must be brought into existence and maintained through social mechanisms of subjectivation, that is, through forms of knowledge and power relations which aim to encourage and reinforce individual subjectivation practices [25].

Homo oeconomicus will integrate or adhere to the market economy through a spontaneous multiplication dynamics, in which it acts according to its interests, expecting the other to do the same and thereby move an economy based on collective interests $[15,26]$. In this direction, homo oeconomicus is an important aspect of the market economy, in its neoliberal version, because, in proportion to its collective interests, it is also acting in accordance with the interests of the economic market [26].
The entrepreneur's relation to the economy is of the political type, because its function is no longer to organize "times and methods" of its productivity in the work of the factory, as the theorists of political economy point out; however, it is a question of providing "... the social construction of the market, in an autonomous productive fabric". In this type of capital, the entrepreneur is one that defines itself with the capacity to function as a link and multiplier, at the same time, its circulation in the economic market, and the optimization of the potentialities of itself [27].

Hoeyer [28] shows that for a capitalist economy to work, people should serve not only as workers, but also as consumers and entrepreneurs. This double function of people, generating more wealth for the capitalist entrepreneur and the national market, also provides global wealth, since it enables the State to establish commercial ties with transnational corporations.

In addition to commercial interests, economic subjects live their biosocialities in terms of responsibility for their health [24,25]. Given that people are exposed to various hazards, speeches from physicians, and more recently from commercial companies in Regenerative Medicine, so this has driven actions of a variety of people to govern their lives and health. In another work, we have already pointed out that the valuation of the genetic code and neoliberal strategies of infusing market values into social and affective relations are elements of the business logic of oneself, in which life gains an entrepreneurial dimension in policies of subjectivity in which health is taken as a good [29].

The analysis of self-management allows one to think of the families that store their children's umbilical cord blood in stem cell banks, not only from an economic point of view, but also from the point of view of those who make the decision to store the cord umbilical. People who employ private umbilical cord stem cell collection and storage services become entrepreneurs in managing their own bodies by choosing which company is most interesting and most secure in the financial and affective investment of umbilical cord her baby, as we can observe in a testimony left by a mother in the company Cordcell:

"Preserving the stem cells from our son's umbilical cord was the best investment we ever made. And choosing the Cordcell was really a wise choice, the process was quick, the staff excellent. He could not name another company other than Cordcell. This act was the greatest proof of love we could give our son" (Source: http://www.cordcell.com.br).

"We were assured and reassured to choose CordCell again, to collect and store the stem cells of our second child, as we did with our first child. This time, we will keep the cells of the blood and the tissue of the cord, accompanying the technological advances". (https://cordcell.com.br/)

"CordCell has been with us since our first child, and now we are going to save the tissue stem cells from Juliet, too, which is news to us. Thank you CordCell, for taking care of the health of our babies!". (https://cordcell.com.br/)

The individual interest of the parents in offering a safe life for their family converges with interests of the private companies, 
moving the flows of capital in Regenerative Medicine. In Foucault's analysis [15], economic man becomes a machine that will produce income streams, which mobilizes all aspects of human life into a marketing network, including areas that are not immediately and directly economic: houses, families, people - all are managed in the form of a company [15]. In this perspective, preserving stem cells from the umbilical cord is an investment made for and in the family in the long term.

The sequencing of our genes and their mutations also cooperated so that we would be able to administer and control our bodies also at a molecular level, considering the possibility of introducing into them the materials produced by biotechnologies in the development of some adverse condition. It is the idea, according to Cardoso and Castiel [23], of a regulatory self-management, in which people resemble "a portfolio manager of equity stocks who, in the face of market instabilities, informs their client of what is happening, puts it before the calculated 'risks' and leaves it autonomous to make its decision ".

Technological choices create a process of continuous regulation of risks, that is, to the extent that people seek strategies for prevention and intervention in their own lives, they are responsible for themselves and for their behavior in relation to health. Risks concern what is not yet current, but virtual, and surveillance or self-vigilance expands regardless of whether we are healthy or not, "pointing to another regime of power that operates in an open environment, beyond the conventional institutional borders" [14].

The way stem cells from the umbilical cord structure their speeches make people to become experts in themselves and their close relatives. The promising speeches and cures implanted by biomedicines have added new concerns to the practices of parental care with the baby: assessing the importance of storing the child's umbilical cord, which bank should be chosen to carry out this activity and accepting the possible future risks of the decision.

I am evaluating Umbilical Cord Blood Banks located in different Brazilian states. What should I take into consideration when deciding?

"We must consider that the collected Umbilical Cord Blood must be processed as soon as possible. Although the Brazilian legislation allows this interval to be up to 48 hours, medical experience reports a progressive loss of cellular viability even within this time frame. Therefore, if the quality of the seats is comparable, it is more prudent to store in the Institution closest to your city" (Source: Criocord - http:// www.criocord.com.br/).

Franklin [30], when analyzing the capitalization of life through the genetic imagery about the film Jurassic Park, emphasizes that more and more Regenerative Medicine people and companies adopt terminologies borrowed from genetics and the theory of evolution as political, commercial, and political speeches. Affective It is worth pointing out that the author brings the dimension of the imaginary not as a symbolic structure of psychoanalytic analysis, however, as a way of thinking the fantasies and fears in relation to recent discoveries and promises provided by genetic technology. In this sense, the genetic imaginary refers to the way in which life itself mobilizes hope and fear of people, at the same time as it is considered as a source of value that can be patented and privatized.

People's daily concerns about the storage of the umbilical cord, collection and future diseases that can be treated are mixed with those already considered common and that were built by the medicalization of pregnancy performed by the obstretes in the 1940s to 1960s, in Brazil. The company Cellpreserve, for example, directs to the stem cell marketing network the management of various aspects of the life of a pregnant mother:

"We are not only concerned with ensuring your tranquility, we are also attentive to your gestation, postpartum and baby care. Therefore, we hold a series of events and lectures on important topics such as: Nutrition in pregnancy, Breastfeeding, Baby care, Use of stem cells, etc. They are doctors, nurses, pharmacists, and a whole host of highly trained professionals to provide you with all the information you need for a healthy gestation and a quiet posture" (Source: http:// www.cellpreserve.com.br).

Expectations, fears, anxieties, and capital flows tied to entrepreneurship themselves blend and form the basis of negotiations between parents and stem cell banks. In these companies, affectivity is being used to mediate actions in the present oriented toward future interventions in the bodies. In another testimony from a mother who stored her daughter's umbilical cord blood at the Brazilian company Cordcell, we see that investing in umbilical stem cell services sets up an ideology of genetic heritage and safety for the children, even if it does not need to be used such cells:

"I have decided to preserve the Mariana's change-cells as an act of love and to ensure any future eventuality. The process was very simple and fast, I am very satisfied with the structure that Cordcell provides and I feel confident in the whole process, because the importance of the preservation of the stem cell is so great, the idea is that it is not necessary to use it, but since we do not know tomorrow, if we have to use it, we have another tool available to help in any eventual situation, so I suggest to all mothers who are able to do this process, for the love of their children" (Source: http://www.cordcell.com.br).

In this perspective, stem-cell banks "materialize the market for bonds and bodies organized by real, potential, biological and cultural codes, maps and disabilities, and at the same time accentuate fear" [29]. As Waldby [10] points out, the suspicions about the clinical value of the private storage of umbilical cord blood are dissolved by their speculative value and the future possibilities that the family can provide. In a climate of generalized anxiety, storing the umbilical cord for individual use is considered as an act of love and hope. Responsibility for the future of children is becoming an increasingly private bond between parents and biomedicine. In this context, stem-cell banks occupy a strategic place, as they offer parents the necessary services that shape parental 
Citation: Rodrigues RV, Galindo D, Lemos FCS. Subjectives and biotechnologies in umbilical cord-trunk bodies: Addresses to psychology. $J$ Psychol Cognition 2019;4(1):6-14.

responsibility and strengthen family ties, according to Brown and Kraft.

The companies of Regenerative Medicine, of which the stem cell banks are part, are configured as new developments in the market economy of contemporary biopolitics. The collection and storage techniques of umbilical cord stem cells are responsible for several institutions for the bioeconomic circuit: institutions involved in DNA sequencing; private companies and public organizations of stem cells and biotechnologies; industries. In this logic, we are supported by associations of heterogeneous elements which can be recombined in a way that gives rise to new groupings, which outline the kind of people we have become, entrepreneurs of our bodies, our health and managers, minimally useful time our lives.

We have come to ground our ethical practices in an understanding of ourselves as creatures inhabited by a deep inner space, the source of all our desires and the secret source of all our problems. But these relationships with ourselves are being transformed into the truth games of molecular biopolitics. That deep space has become shallower, shallower, to be displaced by a direct mapping of personality and its diseases, over the body or brain, which then becomes the primary target for ethical issues [2].

According to Lazzarato [31], in contemporary capitalism, people, their subjectivities and their worlds are merged with the relationships of companies, because companies and their products establish a world inscribed in the bodies of consumers. People, in turn, must respond to this world. This relationship between company and consumer occurs through techniques that are not exclusively disciplinary, but which also occur through the creation and realization of affective feelings, desires, interests on both sides [31].

Thus, managing the life translated into biocapitalis presupposes the increasing action of companies and technologies, multiplying the practices of consumption and marketable goods, among which the one of security. Proliferating services that aim to ensure and protect from uncertainty, as well as revealing the acceleration of the anticipation of the future expressed in the calculations of susceptibility and in a market of biological investments [29]. In this scenario, the figure of the indebted man emerges, since the capitalization of life has made possible perennial control games in which the subject is the one who is always in debt, since he is a consumer [32].

For Lazzarato [33], the current economic crisis, "... in order to establish the power of private property, the articulation between 'production' and 'production of subjectivity' is based on debt and man indebted ". This crisis, which is defined as the crisis of governmentality, redefines both the governed (the indebted man) and the government (technical government), which are now privatized [34]. Added Lazzarato [33]:

The crisis brought to the forefront of debt and its modes of subjection, the man in debt. Now that the promise of riches for all, through hard work, credit, and finances is empty, the class struggle turns to the protection of creditors and the owners of "real estate values". The indebted man, immediately guilty and responsible for his fate, must bear the economic, social, and political failures of the neoliberal power bloc - failures poured out by the state and the business world on society.

In the introduction of the book The factory of the indebted man. Essay on the neoliberal condition, Lazzarato argues that the social paradigm in which we are involved today is defined by credit and the translation of the "debtor man". The market economy is inseparable from the production of "self-worker" subjects and their credible morality. In other words, the debt economy coincides with the production of economy and subjectivity.

In an interview with Antonio Alia, Vincenzo Boccanfuso and Loris Narda, in 2012, Lazzarato maintains that the creditordebtor relationship is organized around a property, including property as materialities and immaterialities. From this perspective, the body, the workforce along with emotions and feelings can be marketed and monetized in the debt economy. This relationship does not need money either, since it does not distinguish between employees and the unemployed, material and immaterial work, salaried and self-employed, since we are all indebted.

Lazzarato [33] also shows that the indebted man emerges with the decline of the self-indulgent man and neoliberal politics, being only the individual guilty and responsible for his debts. We agree with Lazzarato [33], when he argues that there is an increasing relationship between man and debt. However, by analyzing the Brazilian context, we think that the indebted man is an extension of the entrepreneur of himself, in Brazilian liberal-democratic politics. In the current economy, we are always owing, and continually new methods are created to make a person more healthy, therefore, an entrepreneurial and indebted subjectivity, according to Bernardes and Guareschi [32].

The figure of the indebted man, linked to the commercialization of stem cells of the umbilical cord, translates the image of consumers who choose and pay to use the advances of medicine and biotechnics annually. They are also learning "to demand information from doctors, to wait for successful therapies, and to be ready to complain or even to sue when disappointed" [1].

As Cardoso and Castiel [23] point out, the genes we carry are performing the conception of a genetic self, our identities are marked by the interiorization within a molecule, such as the internalization that characterized the birth of the clinic and the instauration of a new look about the body's signals. Today, biotechnicians tell us who we are and what responsibilities and rights we have. The subject is produced in terms of what the human being is dealt with: acting as a subject of law and duties to his health and longevity and indebted, as he invests his financial capital and his body in genetic breeding. The body has become a packet of information, a marketable genetic and statistical reservoir, with which we have been launched into the biossocial domains [35]. 


\section{Final Considerations}

The marketing strategies of the private banks of umbilical cord stem cells, through testimonies of parents who have stored the umbilical cord of their children, have implications for the psychological knowledge in the way in which subjectivities are being forged, which are characterized by fear in relation potential illness, precaution against future illnesses and selfmanagement and indebtedness, in the management of their bodies and their financial and affective interests. As Rose [2] emphasizes, technology does not massacre subjectivity; on the contrary, it mediates the possibility of relating to ourselves as subjects of a certain kind, in our case, as parents who are betting on advances in biotechnologies.

The insertion of stem cell biotechnologies into the daily lives of people mediated by stem cell banks is, in fact, of Psychology, since they encourage us to think about what kind of people, mothers, fathers, families, of social relations and selves are being forged in the practices of collection and storage of the umbilical cord. Pimentel and Bruno [14], exploring the relationship between biotechnologies and subjectivities, point out that biotechnologies are part of the ego constitution, when they bring certain domains of self to us, once the practices of caring for the body are they become more constant and intense with the opening of the genetic code. Still according to the authors, our bodies, in the contemporaneity, are performed by couplings of biological and technological domains.

Lazzarato [33], analyzing Felix Guattari's thoughts on subjectivity, argues that "the central project of capitalist politics consists in the articulation of economic, technological, and social flows with the production of subjectivity." For the author, the market economy needs not only capital, enterprise, flows of economy, but also of subjectivities, since the production of subjectivities can not be dissociated from that of economy and politics. In this way, subjectivity, as Foucault [36] points out, is no longer thought of as a device of spirituality and a practice of truth about the subject, becoming the ethical form as the subject relates to himself and to the other, to care practice.

In the Brazilian and private banks of umbilical cord stem cells, hopeful speeches about an immune future of pathologies and the expectation of increased longevity are some of the reasons that drive and move much of their activities. In these banks, we see strategies aimed at the commercialization of life, regulated mainly by affective policies. The affective life of the people is the target and condition for new contemporary forms of governmentalality [37], in which relationships of affection and love are tools of power and control of the bodies and arrange ways to capitalize one's life.

In addition to effective measures, what is seen in Brazilian cord blood stem banks are rhetorical speeches and promises to turn the scarcity of cellular therapies into abundance and to develop new forms of healthy body by using the resources for the production of body devices less vulnerable to aging and time [10]. Bodies become economic potentials of knowledge and practice, with forms of self-government articulated in the quest for health and longevity.

The analysis of the testimonies on the homepages of Brazilian private banks reveal that, despite the so-called scientific advances, the promised happiness still remains unwarranted. Cardoso and Castiel [23], at the conclusion of a paper on genetics and collective health, underline concern that biotechnology efforts to map and sequence "genetic problems" do not succumb to determinism and deification, fetishization and / or dogmatization of genetic risks. Fifteen years later, we shared such concerns.

In conclusion, we point out that health investment - of which banks are only one of the ramifications - as a patrimony undertaken by the Brazilian middle classes and the market created around them open up a field of questions about subjectivation processes that matter, because they point out that each new private investment is also a resignation to inequalities in which there is no question of a possible equitable distribution of the biological capital in question, not even the possibility of its non-capitalization. The testimonies present in the electronic pages of the private banks make us inquire about the imperative of the patrimonial security of the cells of the bodies, this new moral obligation for those who can contract the offered services.

\section{References}

1. Rose N. Inventing our selfs: Psychology, power and subjectivity. Petropolis, RJ Vozes. 2011.

2. Rose N. Molecular biopolitics, somatic ethics and the spirit of the biocapital. In: Santos LHS, Ribeiro PRC (eds.). Body, gender and sexuality: Instances and practices of production in the policies of life itself. Rio Grande: FURG. 2011.

3. Foucault M. Technologies of the self and other related texts. Barcelona, Buenos Aires and Mexic. Paidós Ibérica. 1990.

4. Santoro P. From (public?) Waste to (private?) Value. The regulation of private cord blood banking in Spain. Science Studies. 2009;22:3-23.

5. Rose N. The politics of life itself: Biomedicine, power and subjectivity in the 21st century. Sao Paulo: Paulus. 2013.

6. Galindo D. Scientific Data as Argument: The case of reduction of sexual partners in AIDS. Masters dissertation. Graduate Program in Social Psychology. Pontifical Catholic University of São Paulo, São Paulo, Brazil. 2002.

7. Galindo D, Ribeiro FRG, Spink MJ. Critical Incidents as a starting point for unwrapping networks. In: XIV National Meeting of the Abrapso, 2007. Rio de Janeiro. Anais. Rio de Janeiro: ABRAPSO. 2007.

8. Galindo D, Rodrigues RV. Critical Incidents, a thread of Ariadne in Documentary Analysis. In: Spink MJ, Brigagão JIM, Nascimento VLV, et al. (eds.). The production of information in social research: Sharing tools. Rio de Janeiro: Edelstein Center for Social Research. 2014;pp: 167-82. 
Citation: Rodrigues RV, Galindo D, Lemos FCS. Subjectives and biotechnologies in umbilical cord-trunk bodies: Addresses to psychology. $J$ Psychol Cognition 2019;4(1):6-14.

9. Vandersen DSO. Discourse as an element of articulation between archeology and the genealogy of Michel Foucault. Dissertation (Master in Philosophy) - Center for Human and Social Sciences, State University of Western Paraná, Paraná. 2008.

10. Waldby C. Biomedicine, tissue transfer and Intercorporeality. Feminist Theory. 2002;3:239-54.

11. Avelino N. Governmentality and liberal democracy: new approaches in Political Theory. Brazilian Journal of Political Science. 2011;5:81-107.

12. Foucault M. In defense of the Society. Sao Paulo: Martins Fontes. 2005.

13. Castiel LD, Álvarez-Dardet C. The Persecutory Health. Rev Saúde Publica. 2007;41:461-6.

14. Pimentel CP, Bruno FG. Body, subject and visibility: implications of biotechnologies on the topic of interiority. Interactions. 2006;22:39-56.

15. Foucault M. The Birth of Biopolitics. São Paulo: Martins Fontes. 2008.

16. Ortega F. Biopolitics of health: reflections from Michel Foucault, Agnes Heller and Hanna Arendt. Interface Comunic., Saúde, Educ. 2004;8:9-20.

17. Czeresnia D. The concept of health and the difference between prevention and promotion. In: Czeresnia D, Freitas CM (eds.). Health promotion: concepts, reflexes, trends. Rio de Janeiro: Ed. Fiocruz. 2003;pp:39-53.

18. Foucault M. Problem of the Subject: Psychology, Psychiatry and Psychoanalysis. Collection Ditos e Escritos I. Rio de Janeiro: Forensic University. 1999.

19. Guareschi NMF, Azambuja MA, Lara L. In: Biotechnologies and (R) evolution in modes of subjectivation. Psychology in Study. 2012;17:5-14.

20. Castiel LD. Health, risks and hyperprevention. Acta Paul Enferm. 2011;24:34-5.

21. Rabinow P. Anthropology of reason. Rio de Janeiro: Relume Dumará. 1999.

22. Castiel LD, Guilam MCR. The Persecutory Health: to the sphere of portable scratchers. Interface: communication, Health, Education. 2007;11:145-63.

23. Cardoso MHCA, Castiel LD. Collective health, new genetics and market eugenics. Cad Saúde Pública. 2003;19:653-62.

24. Lazzarato M. Biopolitics / Bioeconomics. In: Steps ICF (ed.). Power, normalization and violence: Foucaultian incursions for the present. Belo Horizonte: Authentic Publisher. 2013.

25. Hamann TH. Neoliberalism, Governmentality, and Ethics. Foucault Studies. 2099;pp:37-59.
26. Guareschi NMF, Lara L, Adegas MA. Public policies between the subject of rights and homo oeconomicus. Psycho. 2010;41:332-9.

27. Lazzarato M, Negri A. Immaterial work: Forms of life and production of subjectivity! Rio de Janeiro: DP and A. 2001.

28. Hoeyer K. Person, Patent and Property: A Critique of the Hypothesis Commodification. BioSocieties. 2007;2:327-48.

29. Galindo D, Lemos FC, Rodrigues RV. Life as biocapital biological futures, a bet of private banks of umbilical cord stem cells in Brazil. Athenea Digital. 2014;14:255-74.

30. Franklin S. Life Itself: Global Nature and the Genetic Imaginary. In: Franklin S, Lury C, Stacey J (eds.). Global Nature, Global Culture. London: Sage. 2000;pp:188-227.

31. Lazzarato M. From capital-labour to capital-life. Ephemera. 2004;4:187-208.

32. Bernardes AG, Guareschi N. Self-production strategies and biotechnologies. Psychology in Study. 2007;12:151-9.

33. Lazzarato M. Signs, machines, subjectivities. São Paulo: Edições Sesc. 2014.

34. Lazzarato M. Subverting the machine of infinite debt. In: Alia A, Boccanfuso V, Narda L (eds.). Interview with Maurizio Lazzarato. São Leopoldo, RS: Instituto Humanas Unisinos. 2012.

35. Pelbart P. Life and death in a context of biopolitical domination. In: Contemporary Fundamentalism In Question 2008. São Paulo. Anais São Paulo: IEA/USP. 2008;pp:1-21.

36. Foucault M. The hermeneutics of the subject. São Paulo: Martins Fontes. 2006.

37. Anderson B. Affect and biopower: Towards a politics of life. Trans Inst Br Geogr. 2012;37:28-43.

\section{*Correspondence to:}

Flavia Cristina Silveira Lemos

Associate Professor II of Social Psychology

UFPA / Federal University of Pará

Rua Augusto Côrrea, Number 01

Neighborhood: Guamá

Belém, Pará -PA 66075110

Brazil

Tel: 5561999269887

E-mail: flaviacslemos@gmail.com 